Georgia State University

ScholarWorks @ Georgia State University

$1-2-2010$

\title{
Comparative Employment Relations: Institutional and Neo- Institutional Theories
}

Bruce E. Kaufman

Georgia State University, bkaufman@gsu.edu

Follow this and additional works at: https://scholarworks.gsu.edu/uwrg_workingpapers

\section{Recommended Citation}

Kaufman, Bruce E., "Comparative Employment Relations: Institutional and Neo-Institutional Theories" (2010). UWRG Working Papers. 137.

https://scholarworks.gsu.edu/uwrg_workingpapers/137

This Article is brought to you for free and open access by the Usery Workplace Research Group at ScholarWorks @ Georgia State University. It has been accepted for inclusion in UWRG Working Papers by an authorized administrator of ScholarWorks @ Georgia State University. For more information, please contact scholarworks@gsu.edu. 
Andrew Young School of Policy Studies Research Paper Series

Working Paper 10-03

January 2010

Department of Economics

W.J. Usery Workplace Research Group

\title{
Comparative Employment Relations: Institutional and Neo-Institutional Theories
}

\author{
Bruce E. Kaufman \\ Georgia State University
}

This paper can be downloaded at:

http://aysps.gsu.edu/2010_working_papers.html

The Social Science Research Network Electronic Paper Collection: http://ssrn.com/abstract=1565567 
Working Paper 2010-1-2

January 2010

\section{Comparative Employment Relations: Institutional and Neo-Institutional Theories}

\section{Bruce E. Kaufman} Georgia State University 
Comparative Employment Relations: Institutional and Neo-Institutional Theories

\author{
Bruce E. Kaufman \\ Professor, Department of Economics and Senior Associate, W.T. Beebe Institute of Personnel \\ and Employment Relations, Georgia State University \\ \& \\ Research Fellow, Centre for Work, Organization and Wellbeing, Griffith University
}

November 11, 2009

Email: bkaufman@gsu.edu

Chapter for Michael Barry and Adrian Wilkinson, eds., Edward Elgar Handbook of Comparative Employment Relations. 
Comparative Employment Relations: Institutional and Neo-Institutional Theories

Comparative employment relations (CER) has enjoyed a resurgence of interest and scholarly research in recent years. A significant reason is the rising tide of globalization and its present and future impact on employment relations institutions and practices. Rather quickly the furthest corners of the Earth have become interconnected in an international division of labor and system of market exchange, inevitably raising questions about the nature and extent of change in national employment relations systems and the degree to which they are converging to a similar model.

As all participants know, CER is an incredibly large and complex undertaking because of the huge diversity in employment relations systems (ERSs) across nations and the large complications introduced by differences in languages, cultures, institutions, and legal systems. This has made theorizing in CER particularly difficult and challenging. Illustratively, international/comparative textbooks typically have at best a modest discussion of theory and for the most part consist of a chapter by chapter descriptive review of major labor institutions and laws across countries (e.g., Bean, 1994; Van Ruysseveldt, Huiskamp and van Hoof, 1995; Bamber, Lansbury, Wailes, 2004). Also indicative of the under-developed and challenged nature of CER theory are these comments by well-recognized people. Jack Barbash begins the volume Theories and Concepts in Comparative Industrial Relations (1989: 3) with the statement, "If we are not bound by one theory it is just possible that common values inform our work,” while in the mid-1990s Richard Locke, Thomas Kochan, and Michael Piore (1995: xv-xvi, emphasis added) assert, "The last major attempt to develop a comprehensive framework for thinking about national differences in industrial relations was the Ford Foundation's interuniversity study, a 
project initiated in the late 1950s." Still more recently, Richard Hyman (2004) asserts that not only in the early $21^{\text {st }}$ century does the ER field still lack a common theoretical corpus but attempts to develop one for cross-national comparative work are "neither possible nor desirable" (p. 267) because cultural and institutional diversities are so large they effectively preclude useful and reliable generalization.

Part of the scholarly mission is to advance scientific knowledge and nothing is more essential to this task than theory. One must ask, therefore, whether things on the theory front in CER are really as dark as these quotations suggest? As this review demonstrates, the answer is No and, indeed, a steady stream of theoretical models and insights have appeared in the CER field over a several decade period. On the other hand, this review also affirms that theorizing in CER is in indeed a challenging exercise and certainly to this date no consensus theory or paradigm has emerged. Rather, what we have are diverse frameworks, theories and models that highlight key actors, institutions and forces that shape ERSs at a point in time and cause them to change over time. These frameworks, theories and models have come from several different disciplines and schools of thought, including radical/Marxist sociology, neoclassical economics, and international human resource management (HRM).

Situated more or less in the middle of this literature and occupying the largest space are theories and models that are broadly known as "institutional" and "neo-institutional” (INI). The institutional perspective in CER was large in the immediate post-World War II period, went into eclipse in the 1970s-1980s, and has rebounded as neo-institutionalism (or "new institutionalism") during the last twenty years. The center of gravity was originally in economics and the USA, since the early 1990s it has shifted to Europe and sociology and political science. 
The INI literature on comparative employment relations, because it crosses disparate disciplines and different countries, has to date existed in a rather fragmented and non-integrated state. To help remedy this situation, and also to provide easier access to this field of study for people coming to it for the first time, I undertake in this chapter a review and synthesis of the institutional-oriented literature on CER. Other useful if somewhat differently focused reviews are provided by Strauss, (1998), Godard (2004), Martin and Bamber (2004), Hamann and Kelly (2008), and Hall and Wailes (2010). The review here is limited to issues of theory and to the English language portion of the field.

\section{Definition, Boundary and Specification Issues in CER}

The first issue a person faces in exploring comparative employment relations is the question: what is CER? This question is worth asking because there is evident diversity of opinion on this matter and it introduces a similar diversity into CER theorizing and dialogue (Strauss, 1998).

Other chapters in this volume, and particularly the introductory chapter by the volume editors, consider in some depth the domain and major subject areas in CER so I only broach certain key issues here as they bear on theorizing. These issues fall into five categories.

The first is the subject area that CER covers and that a theory therefore needs to explain. One sees in the literature both a broad and narrow conception of CER's subject territory (Crouch, 1993; Budd, 2004: Kaufman, 2008). The narrow conception focuses on collective aspects of employment relationships and, in particular, differences across countries in union density, union structure, collective bargaining practices and outcomes, and union-related labor laws and institutions. The second and broader conception focuses on employment relationships of all types and, in particular, variation across countries in employment institutions and outcomes such 
as the occupational and industrial distribution of employment, wage structures and inequalities, extent of female employment and child labor, degree of state regulation of employment conditions, and the various union-related topics already mentioned.

A second issue concerns the difference between comparative ER and international ER. Sometimes the terms are used more or less interchangeably; experts in the field (e.g., Poole, 1986; Bamber, Lansbury, and Wailes, 2004), however, often treat them as separate if substantially overlapping. The domain of international ER is the study of employment systems in different countries, with an emphasis on description and case-by-case analysis (e.g., Blum, 1981; Doeringer, 1981; Ferner and Hyman, 1992). Comparative ER, on the other hand, involves an explicit comparison of ER systems across two or more countries with the intent to identify common patterns and theoretical generalizations.

A third issue is the nature of the dependent variable in CER theorizing. A review of the literature reveals studies have used three different specifications. The first dependent variable is a measure of the institutional architecture of an employment relations system, such as the degree of centralization in wage determination. A second dependent variable is an employment relations behavior or outcome, such as cross-national variation in union density or income inequality. A third dependent variable measures some aspect of employment relations performance, such as national GDP or employment growth.

A fourth issue concerns the level of analysis in CER theorizing. Differences in employment relations architectures, outcomes and performance can be examined at a firm, industry, regional, national, or international level. Most CER studies use the national level and look at variation in employment relations institutions and outcomes across nation states. However, many nations exhibit distinct variation in employment relations across firms, 
industries and regions (e.g., services versus manufacturing; northern versus southern Italy) and quite possibly this within-country variation is as interesting and revealing as the across-country variation (Katz and Darbishire, 2000; Crouch, 2005). Methodologically, one can also argue that a macro theory of cross-national differences in employment relations needs to be built on a consistent micro version developed at the firm level.

A fifth issue concerns the range of countries included in CER theorizing. Conceptually one would think all countries are included; for theoretical, practical and ethnocentric reasons, however, most researchers limit the list and exclude or greatly minimize countries classified as less developed (LDCs), micro states, or socialist (e.g., Zimbabwe; Luxembourg, Cuba). Regarding LDCs, a theoretical reason is that a large portion of jobs in LDCs are either in agriculture or the informal sector and thus these countries have neither the labor movements nor conventional employment relationships that are the traditional objects of analysis in CER; similarly, in socialist countries the EIR systems may well be non-comparable with those in capitalist countries. A practical reason is that data on employment structures and outcomes are often not available or the sample size is too small for LDCs, micro states and socialist countries. Also entering the picture is ethnocentrism as one finds that most writers come from a small number of advanced western countries and their attention tends to focus on these countries, with the USA, Britain and Germany leading the list.

Setting the Stage: Employment Relations Theory As now viewed by the majority of researchers, the field of Employment Relations (ER) deals with the subjects of work; the structure, management and regulation of the employment relationship; and the quality of work life (Edwards, 2003; Kaufman, 2004a). This field was until 
recently called Industrial Relations (IR) and, indeed, the two names co-exist and are used more or less interchangeably.

The ER/IR field (hereafter EIR) typically looks at employment relations in the context of a particular country and thus the nation state becomes the standard unit of analysis. Further, the most common theoretical approach in EIR is to look at a nation's employment relations as a system (described more below). Thus, it is common to talk about the American EIR system, the French EIR system, and so on.

The task undertaken by CER is to broaden the focus of analysis from the individual nation state to a cross-country comparison of EIR systems. In particular, a principle goal of CER is to understand and explain the differential structure, function and performance of alternative EIR systems. To the degree possible, one would like a theory, model or at least conceptual framework to help guide and illuminate this investigation. But where should one look?

Perhaps the most obvious answer is to search among existing EIR theories that pertain to the individual nation state and then see if they can be broadened/expanded to explain crossnational variation. The subject of international economics, for example, is largely an application of demand/supply theory developed for individual goods and countries to issues of global finance and trade; in similar fashion one could well think that what is called for is not an entirely new and novel theory of CER but, rather, an application of existing EIR models, theories and frameworks to cross-country comparison.

A number of books and articles have been written on EIR theory so no comprehensive review need be undertaken here (see Adams and Meltz, 1993; Edwards, 2003, Blyton and Turnbull, 2004; Kaufman, 2004b; Müller-Jentsch, 2004). Certain salient points and important studies deserve highlight, however. 
It must first be admitted that development of a formal theory of EIR has made only modest and incomplete progress. The first self-claimed attempt to develop a "general theory" of industrial relations is by John Dunlop in his book Industrial Relations Systems (1958). His model will be reviewed below so I postpone detailed description of it. What merits comment here are two aspects. The first is that the system idea is Dunlop's most influential conceptual contribution to EIR theory; the second is that in most people's eyes Dunlop's model is a useful conceptual framework but is not a theory of employment relations per se - at least if the desideratum of a theory is a testable hypothesis.

A second relevant point about EIR theory is that authors build their models around different core features of the employment relationship. Flanders (1965), for example, theorizes IR as a model of “job regulation;” Barbash’s (1984) model explains workplace conflict as the collision of management's drive for efficiency and low cost and employees' desire for good pay, conditions and security; Kochan, Katz and McKersie (1986) select strategic choice as the key variable explaining different EIR configurations; Begin (1991) derives alternative ERSs based on different organizational architectures; Hills (1995) portrays ERSs as built around different systems of workplace control; Marsden (1999) derives alternative ERSs as an outcome of EIR practices that constrain opportunism and free-riding by employers and employees; Budd (2004) makes the central focus of EIR the balanced attainment of efficiency, equity and voice; while Kaufman (2010) argues that the core concept in EIR theory is the human nature of labor. Some of these models are similar to Dunlop's in that they largely serve as useful taxonomical guides and frameworks; several, however, go further and yield testable hypotheses. A particular hypothesis of importance concerns complementarity and, in particular, the idea that EIR 
components are not put together randomly or by "mix and match" but rather are consciously chosen so they fit together as an integrated and synergistic whole.

Third, a large portion of recent theorizing on EIR systems is not taking place in the EIR field itself but rather in contiguous fields such as economic sociology, political economy, and strategic human resource management. North America was the locus of most EIR theorizing up until the late 1980s, after that the EIR field (particularly in the USA) started on a long and cumulatively substantial decline and interest in EIR theory went with it (with certain exceptions, as given by citations above). Other fields picked up the EIR systems idea, albeit typically under different names and labels, and continued to develop it. In strategic HRM, for example, authors have developed different models of employment systems and "HRM architectures" (Lepak and Snell, 1999; Toh, Morgeson, and Campion, 2008); likewise, researchers in the Marxist/radicaloriented labour process field have developed alternative EIR systems built around the concept of "regimes of control" (Edwards, 1979). Of particular relevance to this chapter is the work on EIR systems in economic sociology and political economy, particularly in Europe. Best known under the rubric "varieties of capitalism" (VoC), this literature seeks to theorize the determinants of economic structure, organization and performance within and across nation states. This theory encompasses all dimensions of an economy but a central part in most studies is the EIR system.

Fourth, and finally, the dominant theoretical wellspring of EIR theories is what is loosely called "institutionalism." The field of industrial relations began as a formal entity in the United States around 1920, was positioned as the labor subfield of the institutional approach to economics; and was led by John Commons and other members of the Wisconsin School who were proponents of the institutional approach (Kaufman, 1993, 2004a). Institutionalism in America had strong links to both the discipline of sociology and European-style historical/social 
economics. In America later generations of industrial relationists followed in the institutional and neo-institutional tradition, exemplified by Dunlop, Kochan, Budd and others. The field of EIR was slow to develop in continental Europe and still today has only a modest organized presence (Kaufman, 2004a); hence, this lacuna is mostly filled by sociology and, in particular, economic sociology (aka, socio-economics). One of the fathers of sociology, Emile Durkheim (1895), identified the subject matter of the discipline as the "study of institutions" and, not surprisingly, institutionalism is a particularly strong theoretical tradition in VoC and similar EIR-related work among European sociologists, political scientists, and business theorists.

\section{Institutionalism: A Brief Survey}

Institutionalism has diverse roots going back a century and more (Hodgson, 1998;

Hollingsworth, 2002; Kaufman, 2004a). Its original source was late $19^{\text {th }}$ century German historical/social economics (HSE). HSE was a reaction against two other economic doctrines. One is the English classical and neoclassical economics that largely models economies as a mechanical working-out of commodity exchanges among a mass of unconnected individuals in a highly competitive market place where government, culture, social groups, and legal institutions have little or no role to play. The chief architect of this type of "non-institutional" economics is Leon Walras and his style of general equilibrium economics ruled orthodox economics for much of the $20^{\text {th }}$ century. The second economic doctrine that spurred the development of HSE was Marxist economics and, in particular, Marx's brand of economic determinism that forecast the replacement of capitalism and representative government with socialism and a dictatorship of the proletariat. 
From a neoclassical perspective, differences in employment relations institutions across countries arise from either competitive market forces or the interference of government and other collective actors -- a view first enunciated by Adam Smith (1776/1937). To the degree it is the former, institutions are created by economic agents to facilitate production and exchange and exist as long as they serve this objective. From this functional perspective, institutions do not have independent explanatory power but are creatures of market forces and neutrally transmit these forces. To the degree institutions arise from the interference of government and other collective actors, they serve mostly as agents of redistribution and rent-seeking and, in all but exceptional cases of market failure, interfere with the efficient functioning of the economy. A prominent line of thought in neoclassical economics, and also among "universalistic" theorists in strategic human resource management (Boxall and Purcell, 2008), holds that over the long run globalization, market forces, and profit-seeking will erode and eliminate non-competitive institutions and, hence, economies should converge to some form of competitive market system along neo-liberal lines with a universalistic set of "best practice" HRM methods.

The neoclassical perspective has two large implications for the field of CER. The first is to largely dismiss it as an interesting line of inquiry on the grounds that EIR institutions are substantively unimportant, mostly anti-market, and/or transitory from a long-run perspective. The second is to suggest that if one wants to explain cross-national differences in EIR institutions then the place to start is cross-national levels of economic development -- given the presumption that the configuration of EIR institutions functionally serves economic efficiency and that different configurations are therefore called for at different stages of economic development. The implication is that one should look to neoclassical growth theory to explain cross-national variation in development level and, as illustrated by modern treatises on this 
subject (e.g., Acemoglu, 2009), institutions play a distinctly secondary role and most of the action comes from differences in economic variables such as capital investment, labor force growth, human capital accumulation and technological change.

On the opposite end of the spectrum is Marxist economics. Where neoclassical economics suggests that a market economy leads to harmony, efficiency, growth and a reasonably equitable income distribution, Marxism predicts just the opposite. Capitalism survives and reproduces by exploiting labor to obtain surplus value that is then funneled into further capital investment. Expanded capital investment, however, leads to a falling rate of profit and concentration of industry (i.e., growing monopoly) - both of which lead to a decline in the economy's growth rate and eventual emergence of stagnation. To prop-up profits, employers seek to expand markets through imperialism, colonialism and foreign wars while at the same time they work to reduce production cost by further squeezing labor through speed-ups, longer hours, and hiring of women and child labor. Thus, control and exploitation become the imperatives for employers under capitalism while protection and resistance are the mirror image imperatives for workers (Hyman, 1975; Thompson and Hartley, 2007). Over time class conflict, strikes, and socio-economic polarization grow until a proletarian revolution replaces capitalism with socialism and a workers’ state.

Marxism also has implications for the study of CER. Like neoclassical economics, it also predicts a convergence over time in the nature/shape of national economies and, hence, in EIR institutions and practices. Also like neoclassical economics, it downplays the independent role that institutions play in economic growth. That is, while in neoclassical economics institutions are largely a "veil” for market forces, in Marxism institutions are also largely a veil but in this case for requirements of the production system. That is, in the Marxist schema the "forces of 
production" largely determine the "relations of production" (i.e., social, economic, political institutions). In one respect, however, Marxism leads to the opposite conclusion of neoclassism with regard to cross-national variation in EIR institutions. A neoclassical perspective predicts that over time competitive market forces and globalization should gradually erode and eventually eliminate trade unions and other non-competitive labor market institutions; a Marxist perspective predicts, however, that trade unions, strikes and other institutions of worker protectionism should increase as capitalists intensify their drive for surplus value in the face of mounting economic stagnation and crises.

Institutionalism carves out a middle space between the neoclassical and Marxist paradigms. It combines elements of both but at the same time amends certain key assumptions and introduces new concepts. The end result is that in this paradigm institutions play a central role in structuring and shaping national economies, their growth trajectories, and configuration of EIR practices and outcomes (Hollingsworth and Boyer, 1998; Budd, 2004; North, 2005).

The first key modification in the institutional paradigm is to move away from economic determinism à la Walras and Marx. To do so, institutional theory starts with a more realistic model of the human agent (Commons, 1934; Coase, 1992). People are modeled as purposive, largely self-interested, and intelligent but nonetheless also endowed with significant cognitive constraints, perceptual biases, powerful emotional states, and social orientations. The external environment to the agent is also modified so domains of fundamental uncertainty exist in economic life that cannot be reasonably captured in theory by an assumed probability distribution.

The next key modification is to drop the neoclassical assumption that a stable society, well-functioning government, well-enforced regime of contract law, and a competitive market 
system are somehow exogenously provided. Rather, in institutional theory the major challenge facing every country is to create, structure and maintain an institutional order that provides these things (Coase, 1992). That is, people have to collectively create a government, maintain law and social order, decide the kind of economy they want and the objectives it should serve, and create mechanisms that solve market failures and maintain social peace (Aoki, 2000; North, 2005).

The foundation of the institutional paradigm, therefore, is boundedly rational people who must cooperate in constructing and maintaining an institutional order when they face substantial uncertainty and come to the situation with selfish motives, partially non-rational and destructive emotions, diverse and perhaps divisive cultural/religious/political allegiances, and asymmetric information and objectives. To make progress in constructing an institutional order, these people create organizations called governments vested with sovereign authority to maintain law and order, create a legal code, enforce contracts and establish the infrastructure needed for a functioning economy. These governments define the modern nation state and it is these nation states that become the basic unit of analysis in institutional CER.

In the institutional paradigm there are few "universals" of human behavior, given that human behavior is always embedded in and therefore shaped by diverse cultural, social and historical contexts (Polanyi, 1944; Hollingsworth and Boyer, 1998). Given this, the government and all subsidiary institutions in a nation state are to a large degree context specific and develop along path dependent historical trajectories (Deeg and Jackson, 2007). As in the neoclassical and Marxist paradigms, CER systems across countries reflect stages of economic development; unlike in these paradigm, however, the collectivities of people and ruling elites in each nation determine through a constructed institutional order what kind of economy they have, how it operates, whose interests and objectives it serves, and how problems and disputes are solved. 
The result is a huge diversity in societies, economies and CER systems, considerable persistence and stability in CER institutions, and therefore outside of crisis situations mostly incremental change and only weak-to-modest forces leading to convergence through either market competition or universal requirements of production.

The core proposition of institutionalism is "institutions matter" in predicting an economy’s architecture and performance. However, no one theory of institutionalism commands universal agreement; indeed, Strycker (2002: 53) speaks of a “variety of institutionalisms.” What can be said, however, is that institutionalism in economics, after a 30-40 year downturn following World War II and the neoclassical resurgence, has reemerged since the early 1990s sometimes under the labels “neo-institutionalism” and “new institutionalism” - as a popular and growing area of research. In the USA, economists such as Coase, North and Williamson are prominent names in new institutionalism; in Europe a mix of sociologists, political economists and political scientists have spearheaded the neo-institutional movement. Important names include Amable, Boyer, Hall, Soskice, Streeck, and Thelen.

\section{Anglo-American INI Theories}

The CER theoretical literature can usefully be divided into two parts. The first is in employment and industrial relations proper (the EIR field) and comes largely from authors in AngloAmerican countries. The second is largely centered in European sociology and gives emphasis to theories such as varieties of capitalism. I focus on the Anglo-American set of INI theories in this section and move to those from European sociology in the next.

Micro Theories of Employment Systems 
As discussed earlier, the central organizing concept in CER is the notion of an EIR system. As also earlier discussed, on methodological grounds one can make a good argument that "macro" theories of cross-national variation in CERs should be built on consistent "micro" theories as developed for individual firms, industries and nations. Toward this end, I start here with a brief review of several micro theories of employment relations systems and then move to macro theories. Included in this micro section is discussion of Dunlop's notion of an industrial relations system.

ERS Models. John Commons, the academic co-founder of the IR field and American branch of institutional economics, is also the originator of ERS typologies. In his book Industrial Goodwill (1919) Commons identifies five alternative "theories of labor" - commodity (demand/supply), machinery (scientific management), good will (commitment), public utility (a publicly protected resource), and citizenship (industrial autocracy/democracy) - and discusses how each theory leads to a different model of people management and associated practices. Commons' explanation of these systems is discursive but one finds sprinkled here and there factors that he points to as determinative. The commodity model, for example, is a good fit for low-skill jobs where the work is standardized and easily monitored; the good will model, on the other hand, is good fit where jobs require higher level and more intangible-type skills and where cooperation and good citizenship behavior have particular value.

For the next major ERS contributions in industrial relations we now fast forward to the 1950s. One comes from economist Clark Kerr and the other from John Dunlop.

Kerr $(1950,1954)$ first divides labor markets into "structured” and "unstructured.” The latter is equivalent to Commons' "commodity model" where undifferentiated labor is traded back and forth, turnover is high, demand and supply determine wages and other terms and conditions 
of employment, and employer HRM practices are very bare-bones. The former correspond to what Kerr calls "institutional” labor markets that are structured by various rules, norms, and organizational features created by employers, unions and/or government. He divides structured labor markets into two generic ERS types: “communal ownership” and "private property.” The former is exemplified by an occupational labor market or industry organized by a craft union where jobs require well-recognized skills but the skills are general and therefore portable (e.g., in nursing, construction); the latter is exemplified by a factory or company organized by an industrial union where job access is regulated by seniority and skills tend to be company-specific (e.g., in an auto plant). Of the two, the private property model has the more extensively developed internal labor market (ILM) and HRM system since the longevity of the employment relationship makes all aspects of HRM more important to organizational performance.

Dunlop's contribution to the ERS literature is the concept of an "industrial relations system.” In his well-known book Industrial Relations Systems (1958), Dunlop defines an IR system as "the complex of interrelations among managers, workers, and the agencies of government" where "the parts and elements are interdependent and each may affect other elements and outcomes of the system as a whole” (p. 13). He identified three main actors in an ERS - employers and their representatives, employees and their representatives, and government and its agencies; four main structural components - budget constraints, technology, power relations and statuses of the actors, and labor-management ideology; and made the central explanatory task of the model "why particular rules are established in particular industrialrelations systems and how and why they change” (p. ix). In practice, Dunlop gave most attention to unions and collective bargaining as determinants of the rules of the ERS. Although the influence of Dunlop's book has faded in recent years, for several decades it was paradigmatic, 
per the observation of Cochrane (1979: 97), “The book continues to be the basis for a large portion of industrial relations research around the world.”

EIR theorizing on employment systems next moves to the 1970s and 1980s and two more contributions. The first is Doeringer and Piore (1971). Their contribution is to delineate four factors that create ILMs: skill specificity, on-the-job training, unions, and customary law. Higher levels of these four factors promote more internalization of labor coordination and, hence, a more HRM intensive ERS. The second study is by Osterman (1987). He identifies four dominant ESs: industrial, salaried, craft, and secondary. The nature of these different ESs is evident from their names; what distinguishes Osterman's paper is that he then links different ES models to different configurations of four HRM practice areas - job classification, deployment (staffing), security, and wage rules - and identifies five factors as the chief determinants of ERS selection - goals of the firm (cost minimization, flexibility, predictability), production technology, social technology, labor force characteristics, and government policies.

Our review of the EIR stream ends with recent contributions from the 1990s to date. Three contributions merit brief mention (also see Applebaum, Bailey, Berg, and Kalleberg, 2000; Orlitzky and Frenkel, 2005). First is Arthur (1992). His article is noteworthy because it integrates the IR system idea; the role that strategy plays in shaping ERSs; and the "high performance" model of work organization. He looks at steel minimills, differentiates between "cost minimization” and “product differentiation” business strategies and then examines if they map into a "command and control” or "high commitment” HRM/IR system. Cluster analysis reveals the ERSs in the minimills sort into distinct types in line with the two strategies.

The second contribution is Marsden's A Theory of Employment Systems (1999). The book is almost entirely a work of theory and is based on ideas from institutional economics (IE, the 
“mother paradigm” of IR) and, in particular, works by Coase (1937), Simon (1951) and Williamson (1975). Marsden identifies the constraints on behavior that are necessary for the employment relationship to be a viable economic proposition for both employers and workers; from these constraints he identifies four permutations of job design and skill development in firms' production systems, and in the last section of the book examines specific HRM practices that go with each production system. His theory indicates ILMs and "transformed” HRM systems develop when transaction costs are high and knowledge requirements are high and firmspecific -- conditions created in turn by factors such as interdependent job tasks, tacit knowledge, learning on the job, and difficulty of monitoring job performance.

A third contribution is Kaufman's (2004c; 2010) ERS model. It is similar to Marsden in that it uses IE and, in particular, the transaction cost (TC) concept. He demonstrates that in a world of very low TC organizations dis-agglomerate into small units and HRM systems are "externalized" and "simple;" in a world of very high TC organizations agglomerate into very large units and employment systems become "internalized" and "HRM intensive." Variation of five variables, in turn, causes different ERS permutations between these polar opposites: the degree of bounded decision-making, interdependence in utility functions, interdependence in production functions, indivisibilities and gaps in property rights, and legal restrictions on trade by the sovereign.

Summary. EIR micro theories of employment systems suggest several things for macro theory construction. First, these models suggest that factors external and internal to firms cause employers to configure EIR practices in a relatively small number of discrete configurations. Second, these models suggest that at the most fundamental level ERSs divide into two polar opposites. On one end is a largely market-driven employment system where labor is treated as a 
commodity (a "hired hand"); the firm's strategy focuses on cost minimization; EIR practices and internal labor markets are sparse and porous; workers are likely to feel low commitment and trust; and the employment relationship tends to be viewed by both sides as a zero-sum game. On the other end of the spectrum is a human capital/commitment employment model where labor is viewed as an asset (a "human resource”); the firm’s strategy seeks competitive advantage through superior employee motivation, skills, and behaviors; considerable investment is made in EIR practices, job security and internal labor markets; employees feel considerable loyalty and dedication to the organization; and the employment relationship is viewed by both sides as a positive-sum game. Third, these micro ERS theories suggest that a finer analysis reveals that employment systems sort not just into two opposite ideal types but, rather, into a small number of distinct but complementary systems. Although authors give different names to these employment systems, in generic form they sort into models centered on, respectively, market forces, the technology of production, organizational structure characteristics, occupational norms and skills, and employee motivation and firm-specific skill development - in some cases reinforced by the forces of trade unionism and labor law. Fourth, these theories also pinpoint specific variables that influence firms' choice of ERS systems: for example, the firm specific nature of skills, the degree technology can control and monitor the quantity and quality of work, the importance of human capital in production, firms’ positioning strategy for competitive advantage, economic conditions in product and labor markets (e.g., degree of competition, extent of surplus labor supply), and the relative importance for production of discretionary employee work effort and citizenship behavior.

Macro Theories of EIR Systems 
We now come to EIR theories and models that explicitly address cross-national variation in employment relations practices and outcomes. I winnow the literature and present a synopsis of studies that represent significant contributions and explicit theoretical generalizations, presented in chronological order of publication. Studies with more general but less testable classifications, frameworks and implications (e.g., Dore, 1973; Adams, 1995; Locke, Kochan, and Piore, 1995; Martin and Bamber, 2004) are perforce omitted due to space constraints, although they also offer valuable insights. The same is true for comparative studies limited to specific EIR topic areas, such as unions and collective bargaining (e.g., Hyman, 2001) and multinational corporations (Briscoe, Schuler, and Claus, 2009). As before, the focus is on studies broadly in the institutional and neo-institutional tradition.

The place to start has to be the book Industrialism and Industrial Man by Kerr, Dunlop, Harbison and Myers (1960). This book is without doubt the most ambitious and large-scale study ever done in CER; furthermore, the project secured large-sized funding from the Ford Foundation and sponsored a wave of additional comparative EIR work by scholars from across the world that over a two decade period produced more than forty additional books. The 1950s and 1960s was a "golden age” for the pioneers of CER research; furthermore, the work of Kerr et. al. and collaborators greatly helped spread the industrial relations field beyond its narrow Anglo-American base. Representative titles produced include Human Resources for Egyptian Enterprises (Harbison and Ibrahim, 1958), Industrial Relations in India (Myers and Kannappan, 1970), and Human Resources in Japanese Industrial Development (Levine and Kawada, 1980). Other scholars from a variety of countries were also attracted into the CER field, such as Hugh Clegg, Everett Kassalow, Frederick Meyers, James Morris, Ben Roberts, and Adolf Sturmthal. 
Kerr et. al. spent seven years visiting numerous countries around the world assembling evidence for the book. Remarkably, while hailed as a great work at the time it has since largely faded into anonymity or become a standard reference for critics of the "convergence thesis." Industrialism and Industrial Man takes Dunlop’s earlier IR systems model and extends it to a cross-country comparison; further, while Dunlop’s IR systems model is largely static, Kerr et. al. endeavor to put a dynamic element into it (via the industrialization process). Their thesis is that CER exhibits both unity and diversity. The unity comes from the inexorable process of industrialization - a process well advanced in some countries and only beginning in others which poses through technological and organizational constraints a significant degree of conformity in broad EIR practices and outcomes (e.g., all industrialized countries have large firms, bureaucratic employment systems, and labor movements). The diversity in EIR comes from a variety of factors that are country or region specific: examples include the different industrialization strategies of the ruling elites, diverse cultural and social conditions, and different political and management-labor ideologies. Kerr et. al. predict a "first order” trend toward convergence among nations in the "web of rules" that define national EIR systems as at some point all countries are seen as getting on the industrialization bandwagon; nonetheless, they also predict continued "second order" diversity in the EIR web of rules due to long-lasting crossnational differences in cultural, social and political factors.

Theorizing in CER entered a relatively inactive period during the 1970s and early 1980s. The ice was broken, however, with publication of Industrial Relations: Origins and Patterns of National Diversity by Michael Poole (1986). Similar to the “micro” EIR model of Barbash (1984), Poole defines EIR broadly as “all aspects of the employment relationship” (p. 4) but then designates employer-employee conflict as the central dependent variable of interest (p. 6). Poole 
also follows Dunlop (1958) in making employers, employees, and the state as the three principal actors. He argues that divergent interests between employers and employees characterize the employment relationship in both the spheres of production and distribution; hence, the task of CER theory is to identify the variables that generate conflictive interests and the institutions and practices designed by the three actors to ameliorate and resolve these conflicts. Poole allows that, "at the current state of our knowledge, attempts to establish a general inclusive comparative industrial relations theory are likely to prove fruitless” (p. 198). Nonetheless, he believes it is possible to identify principal variables and causal pathways. In this spirit, Poole identifies the state of economic development, the strategies of the actors, cultural values and ideologies, the nation's politico-economic structure, the power of the actors, and the institutional structure of firms and EIR organizations as principal explanatory variables.

The third CER model examined here is by Colin Crouch in his book Industrial Relations and European State Traditions (1993). It is an example of the genre of CER that focuses primarily on the collective dimension of employment relations; in addition, it represents a precursor to important ideas in the VoC literature surveyed in the next section.

As is true for many other authors, Crouch is critical of many specific aspects of Dunlop’s IR systems model but, nonetheless, utilizes the basic systems idea. His focus in on European countries and the central "dependent variable” is the degree of centralization and coordination of industrial relations between organized capital (Capital) and organized labor (Labor). In this respect, Crouch exemplifies a European tendency to define EIR narrowly as "collective employment relations.” High coordination and centralization is representative of "neocorporatist” EIR systems, such as Germany and Scandinavia; low coordination and decentralization is representative of “pluralist” or “conflictive” EIR systems, such as France and 
Britain. His thesis is that the pluralist/conflict EIR model is the zero-sum (or even negative sum) “default” option, much as in a Prisoner’s Dilemma game, while the cooperative neo-corporatist model creates positive sum outcomes. Both systems exist in modern Europe; hence, the issue for theory is to identify the variables that cause countries to gravitate toward one or the other. Crouch argues that three factors are crucial. First, Labor must be powerful and be able to threaten Capital with large losses, hence motivating Capital to seek accommodation and partnership. Second, Capital and Labor must cover a significant part of the workforce and have centralized organizational structures so they can incorporate diverse constituencies, demands and effects. And, third, both Capital and Labor "peak organizations” must be able to police their members and maintain intra-organizational unity. If these three factors are met, Capital and Labor develop dense interactions and interdependencies, a culture of trust and cooperation, and a problemsolving communication approach that collectively allows them to move from the conflictive/pluralist zero-sum outcome to the neo-corporatist/cooperative positive-sum outcome.

Next is the book Dynamic Human Resource Systems: Cross-National Comparisons by James Begin (1997). Begin, a professor of industrial relations, describes his model as a blend of ideas and concepts from the neo-institutionalist and strategic human resource management literatures. Begin develops a CER theory and then applies it to an explanation of the EIR systems in six nations: Germany, Japan, Singapore, Sweden, United Kingdom and United States. His model is ambitious because he endeavors to not only explain differences in EIR architectures and practices but also cross-national differences in four outcomes: degree of employee competence and commitment; the degree of organizational flexibility; the degree of organizational integration; and level of organizational performance. Unlike Crouch, Begin assumes EIR applies to both union and nonunion employment relations. 
Begin follows Dunlop and theorizes CER in terms of discrete systems; further, he takes the rules of the workplace as an intermediate variable in the causal chain that links external and internal explanatory variables to differences in EIR architectures, practices and performance. EIR systems are decomposed into six subsystems: work/job design, employee development, staffing, workforce governance, rewards, and EIR management structure. According to Begin, one driver of differences in EIR systems across nations is differences in competitive strategies on the part of business firms. Given different resource endowments, levels of technology, and other contextual factors, each nation comes to the global marketplace with different competitive advantages. Government policies, national cultures, and business strategies adapt to align with and exploit these competitive niches. Thus, the competitive advantage of the United States is mass production of consumption goods, Germany's is quality production of differentiated durables and investment goods, and Japan's is technological innovation and high quality manufacturing. Differences in these production regimes lead to predictable differences in EIR systems. Differences in production regimes then interact in a complementary way with other external and internal factors to further differentiate EIR systems. One example in Begin's model is the external state-supported education system and the internal firm-created employee training system. Japan's and Germany's strategy of quality production, for example, is partly conditioned on a state school system that produces large numbers of graduates with top-end reading, math, and science skills and well-developed in-firm training systems where workers get life-long training and skill development in ILMs. The USA, by way of contrast, gravitates toward a mass production EIR system in part because the education system also "mass produces” low-tomedium quality secondary-level graduates and firms rely less on in-firm training systems for needed employee skills than hiring from external labor markets. 
A fifth study providing CER theory with INI roots is Converging Divergences by Harry Katz and Owen Darbishire (2000). It raises an interesting empirical finding vis-à-vis the Crouch study (just reviewed) and the VoC studies coming up. Crouch argues that a centralized neocorporatist EIR system maximizes national performance; perhaps ominously, Katz and Darbishire observe that in seven major European, North American and Asian economies the late $20^{\text {th }}$ century trend in EIR systems is the other way - that is, toward decentralization and deunionization. This common trend in each country provides the "converging" theme for the book. Within and across countries, however, they observe growing dispersion and variety in EIR practices and outcomes and movement toward a larger number of discrete ESs in countries (e.g., Germany) where centralized bargaining institutions once covered most of the field. This increased ES variation provides the "divergences" theme for the book.

Based on their seven country comparisons, Katz and Darbishire identify four discrete employment systems that represent the major options in each nation. They label them: Low Wage, HRM, Japanese-Oriented, and Joint-Team Based. The convergence trend toward decentralization and deunionization, they argue, arises in broad outline from certain common economic forces (globalization, deregulation) and organizational/technological factors (flatter hierarchies, flexible manufacturing techniques). The rapidity and extent of decentralization and deunionization across countries, however, is principally determined by the starting point of each country in terms of the breadth and depth of institutional coordination and regulation of the EIR system; that is, in more coordinated/regulated EIR systems the pace of decentralization and deunionization is slower. In a complementary way, Katz and Darbishire also find that the growth of within-country dispersion in EIR practices varies inversely with the pre-existing level of institutional coordination and regulation. 
A sixth CER study of note is by Jill Rubery and Damian Grimshaw (2003). Reflecting more a neo-Marxist and labour process (or "materialist”) orientation, they argue that central to any theory of CER must be the nature of the production system in each country. Their work falls in the INI tradition, however, because they do not posit a one-way causal arrow from the forces of production to the relations of production, as in classic Marxist theory, but rather two-way interactive arrows where the institutions of the economy also influence the production system. Based on a number of features of production systems, they sort OECD countries into four types: Japanese lean production, German diversified quality production, Italian flexible specialization, and Swedish socio-technical. They then identify the major competitive strategy that accompanies each and the derivative EIR system. For example, the Japanese system features high work intensity, long-term employment security, and enterprise unions; the German system features a highly skilled workforce, extensive training, and strong unions and industry-wide bargaining; the Italian system features small workshops with skilled labour, informal training, and weak and fragmented unions; and the Swedish system features extensive team working, social welfare provisions, and nation-wide collaboration between employers associations and trade union federations.

The final Anglo-American CER model considered here is by John Budd in his book Employment with a Human Face (2004). Budd argues that every EIR system is built around three fundamental structural constraints and desired behavioral outcomes: attainment of efficiency, equity and voice. Attainment of these three outcomes leads to convergence among national EIR systems along certain important dimensions. For example, efficiency dictates that manufacturing firms in a given product line (e.g., autos) adopt EIR systems with certain common job skills, training methods, and horizontal and vertical lines of job mobility; likewise, 
maintenance of internal and external equity dictates that these same firms link pay to individual job performance and provide some formal method for dispute resolution. But diversity in EIR systems is made possible because to some significant degree companies, industries and nations put different weights on efficiency, equity and voice and choose different methods to achieve them. This allows Budd to develop a "geometry" of CER (see his Figure 7.1) where national EIRs sort into different efficiency, equity and voice combinations. A Social Partnership (neocorporatist) form of EIR system, for example, scores relatively high on formal employee voice, low-to-medium on efficiency, and middle-high on equity; a Weak Voluntarist system, on the other hand, adopts EIR architectures and practices that score high on promoting efficiency, flexibility and low cost but score relatively low on both equity and voice.

\section{European-Based INI Theories}

A largely separate but complementary CER theoretical literature has developed with roots mostly (but not exclusively) in continental Europe. As earlier noted, the field of industrial relations was a relative late-comer to Europe (a term hereafter used to mean continental Europe) and never established a significant institutional/organizational home-base in its universities. Further, European sociology has taken within its borders many aspects of the employment relationship, a fact that has also reduced the opportunities for EIR in Europe to development the same degree of autonomy and presence as it has in Anglo-American countries.

Nonetheless, the same forces of globalization that over the last several decades have stirred renewed interest in CER among Anglo-American scholars have also done so among their European counterparts, leading to a parallel resurgence in scholarship in this area. Both literatures have a substantial base in institutionalism but the European branch, being more 
influenced by sociology and political science than economics and human resource management - as well as distinctive European intellectual and ideological traditions, has developed a distinctive theoretical discourse and set of ideas that distinguishes it from Anglo-American theorizing in CER. The differences, however, are often more of emphasis and idiom; further, several Anglo-American authors have made substantive contributions to developing this European-based literature (e.g., Piore and Sabel, 1984; Hollingsworth in Hollingsworth and Boyer, 1998) and in recent years a number of Anglo-American authors have further extended it, particularly with respect to employment relations and CER (e.g., Godard, 2004; Wailes, Kitay and Lansbury, 2008).

EIR-related research in Europe (hereafter “Euro-EIR”) spans disciplines but has its center of gravity in economic sociology, albeit with significant cross-disciplinary contributions from political science and other fields. While Anglo-American EIR traces its roots to founders such as the Webbs, Commons and Perlman, economic sociology looks to people such as Durkheim, Weber, Polanyi, and Marx for foundational ideas. Like neoclassical economists, for example, Durkheim makes the division of labor a central organizing concept for sociology; the difference is that he insists the division of labor is coordinated by more than competitive market forces e.g., power, authority, social norms, custom, and law - and functions within a network of constraining and enabling formal and informal institutions. From this heritage grows two themes that are at the center of institutionalism in modern economic sociology: the social embeddedness of economic life and the coordination role played by institutions (Polanyi, 1944; Hall and Soskice, 2001). Added to these are other concepts, probably the most important and oft-cited are institutional complementarity and institutional comparative advantage. 
Euro-EIR parallels Dunlop in one important respect but then quickly diverges on another. The common element is that both portray EIR practices and outcomes as an interconnected system; the divergent element is that Dunlop argues the EIR system can be treated for purposes of analysis as largely a separate self-contained subsystem of the national economy and society while Euro-EIR argues (reflecting, in part, the stronger influence of Marxism) that the EIR system cannot be divorced from or taken out of the larger economic and social system in which it is embedded. This premise immediately leads to what is perhaps the most distinctive - certainly the most cited - conceptual part of Euro-EIR: the notion that advanced industrial nations sort into varieties of capitalism and, thus, by principles of complementarity and coherence into varieties of EIR systems.

Many writers (e.g., Crouch, 2005) attribute the initial inspiration for the VoC idea to the book Capitalism vs. Capitalism by Michel Albert (1993); by all accounts, however, its most influential and oft-cited source is the edited volume Varieties of Capitalism by Hall and Soskice (2001) and, in particular, the editor's introductory chapter. Behind these scholarly works, it should also be noted, are important real world events, such as the fall of the Berlin Wall and the end of socialism as a seemingly viable economic alternative to capitalism. The sub-title of Albert's book gives a flavor of the argument; it also accurately indicates that the main line of this literature is to some degree critical of an American-style neo-liberal market economy and favorable toward a northern European-type "social market” economy. The subtitle reads: "How America's Obsession with Individual Achievement and Short-term Profit Has Led It to the Brink of Collapse.” This subtitle also reveals, although less directly, another feature of the VoC literature which bears on its utility as a basis for comparative work in EIR. That is, the concept and focus of VoC potentially omits a large number of the world's countries from analysis -- i.e., 
all those lacking relatively modern and mature capitalist economies. Indeed, as a number of commentators have noted, in $\mathrm{VoC}$ the attention tends to be on two countries as the archetypes Germany and the USA or, somewhat more broadly, Germany/Japan and the USA/UK (Streeck and Yamamura, 2001). In recent years some authors have endeavored to broaden the reach of VoC by distinguishing one or more other models, such as an Asian variety of capitalism (Yeung, 2000) and a Mediterranean variety of capitalism (Amable, 2003), although these remain somewhat peripheral to the literature and still effectively leave out many other regions. I should further note that the comparisons in VoC between Germany/Japan and the USA/UK are not entirely novel as an earlier 1980s literature on corporatism focused on many of the same differences in the respective economic systems (Goldthorpe, 1984).

Given these points of context, two different approaches - a deductive (theory-driven) and an inductive (data driven) method -- have been taken to identify different models of capitalism. I start with the deductive approach. It seeks to develop distinct models of capitalism based on a focal theoretical concept; this concept is then used to deduce alternative ideal types (Deeg and Jackson, 2007). Three major focal concepts have been used, respectfully: institutional means of economic coordination; corporate governance systems; and national business systems. To a significant degree, the models that emerge are overlapping, complementary, and nested one in the other.

The first approach distinguishes $\mathrm{VoC}$ on the basis of differences in the mechanism that coordinates market economies (Hall and Soskice, 2001). On one end of the spectrum is reliance on relatively unfettered markets and competitive market forces of demand and supply; in effect, coordination is performed by the "Invisible Hand" of the market. On the other end is reliance on highly structured and regulated markets where market forces get a large degree of coordination 
and guidance from the "Visible Hand" of the state and lower-tier organizations, such as employers' associations and trade unions. The former is typically referred to as a liberal market economy (LME) and the latter as a coordinated market economy (CME) (Streeck and Yamamura, 2001). Corollary features of a LME are a more individualistic cultural ethos, lower union density, a less interventionist government, and a smaller and more porous social safety net; features of a CME are largely the opposite.

The second deductive approach distinguishes VoC based on different forms of corporate governance (Dore, 2000; Gospel and Pendleton, 2005). On one end of the spectrum is the shareholder model of capitalism; on the other is the stakeholder model. In shareholder countries public policy treats corporations as the creatures and servants of their shareholder owners; that is, corporations exist for only one purpose -- to serve the interests of the shareholders - and the shareholders' interests in turn are focused on maximizing the value of the stock shares. Corporate governance, therefore, is structured so that the capital owners exercise dominant if not sole authority in running the company, restrictions on capital investment decisions and mergers/acquisitions are minimized, and financial markets are well developed, highly competitive, and emphasize raising capital through stock and bond markets. Typically managers operate with a shorter time horizon in shareholder countries.

In stakeholder countries, the situation is much the reverse. Corporations are created by the state and while they must operate to earn profits for shareholders they must also serve broader social objectives - with the idea that maximum profit may subtract from accomplishment of certain social goals (e.g., a cleaner environment) and fail to achieve others (a reduction in the length of the workweek). Hence, corporate governance is diffused among different stakeholders so each has a say in the goals and operation of the company, such as 
intended with the German model of codetermination. In stakeholder countries, corporations are more highly regulated, are embedded in a thicker institutional network of trade unions, employers' associations and government agencies, and obtain capital relatively more from banks and governments. Hence, these companies have "patient capital” so executives can make business decisions with a longer-term payback period; likewise, the limits on take-overs and mergers and acquisitions to some degree insulates executives from short-term pressure to raise the stock price and cut operating costs so they can better balance the interests and needs of not only shareholders but also workers and communities.

The third deductive approach makes use of a concept called "national business systems" and makes the focal theoretical construct alternative state strategies for growth and development (Whitley, 1999; 2005). Of all institutions in an economy, the state is the most consequential because it sets the constitutional rules that determine the legal framework of the economy and, therefore, the shape of private organizations, the goals and constraints of individual agents, and the nature of the coordination mechanisms used to bind together transactors. States choose different growth and development strategies depending on various factors, including the composition and objectives of the national elites, the nation's culture and history, sources of comparative advantage, and exposure to international trade. Based on these factors, Whitley (2005) derives four state-created models of capitalism: Arm's Length, Dominant Developmental, Business Corporatist, and Inclusive Corporatist. In Arm's Length countries (e.g., the USA), the state’s growth strategy emphasizes competitive markets and modest-to-little government intervention and encouragement of organized interest groups (e.g., unions, industry associations). Nations using the Dominant Developmental strategy (e.g., South Korea) give the state a large and active role in guiding the economy; further the state dominates or represses intermediary 
organized interest groups. A variant is the Business Corporatist model where the state (e.g., Japan) again plays a dominant role but gives more space to intermediary interest groups with employer associations given high-level access to state policy-makers and labor groups tolerated but given less access. The inclusive corporatist model (e.g., Sweden) is similar except that both organized labor and business groups are given high level access and important coordinating roles.

These deductive models of VoC have been criticized on various grounds (Crouch, 2005; Streeck and Thelen, 2005; Hancké, Rhodes and Thatcher, 2007; Kesting and Nielsen, 2008); for example, for being overly static, deterministic, firm-centered and downplaying conflict and the cross-country role of multinational corporations. Another criticism is that they impose arbitrary and sometimes ill-fitting distinctions upon countries. An opposite approach, therefore, is empirical and inductive where VoC categories are formed by using statistical techniques (e.g., cluster analysis) to sort countries into similar patterns. A good example is Amable (2003). He examines twenty-one OECD economies. Based on a large number of statistical indicators, he finds these countries sort into five relatively distinct models of capitalism. He calls these, respectively, Market-based, Social Democratic, Asian, Mediterranean, and Continental European.

Described to this point are various VoC models and associated theories. For them to be relevant to CER, these models must be used to generate predictions about the architectures and outcomes of EIR systems (Brewster, Wood, and Brookes, 2006). Here enters the core concept of institutional complementarity. What all of these VoC models have in common is that they generate differences in national business systems from non-labor attributes of societies - that is, factors such as state development strategies and different forms of corporate governance. Thus, 
the challenge is to then derive the EIR system that matches the core VoC attribute. Toward this end, INI writers go back to the "systems" idea and posit that the pieces of a national business system are adjusted by economic agents until they (approximately) fit together and interact in a (more or less) functionally coherent and perhaps synergistic manner. This notion of "pieces fitting together” encapsulates the idea of complementarity; also found in the human resource management literature in the form of the "configurational” hypothesis (Boxall and Purcell, 2008). More formally, INI state that two institutions are complementary when, "the presence (or efficiency) of one increases the returns from (or efficiency of) the other” (Hall and Soskice, 2001: 17).

It is useful before going further to remind the reader that in most of the European-based VoC literature (e.g., Hall and Soskice, 2001) the term "industrial relations” is defined narrowly to include only (or mostly) collective employment relations and, in particular, the institutions, laws and practices pertaining to unions, employers associations and other aspects of collective bargaining and voice. In what follows, however, I follow contemporary Anglo-American convention and define IR broadly to include all types of employment relationships, all types of employment practices (including HRM), and all types of social welfare regimes.

The most popular and oft-cited typology in VoC is between LMEs and CMEs (Hancké, Rhodes, and Thatcher, 2007; Kesting and Nielsen, 2008). VoC writers hypothesize that each form of capitalism should utilize a distinctly different EIR system (Hall and Soskice. 2001; Godard, 2004; Wailes, Kitay, and Lansbury, 2008). LMEs, for example, favor competitive market coordinating mechanisms, arms-length and non-interventionist governments, shareholder governance systems, and low levels of organized interest group involvement. These characteristics are hypothesized, via the principle of institutional complementarity, to lead to 
predictable patterns in the associated LME employment system. In particular, the EIR system in an LME should feature more labor market volatility and employment in-flows and out-flows, greater dispersion in employment outcomes (e.g., inter-industry wages, income inequality), more porous and truncated ILMs, low levels of institutionalized employment security, greater labor flexibility for firms, greater emphasis on competitive advantage through low cost production and frame-breaking product innovation, more reliance on buying skills in the market rather than inhouse development, a relatively porous and thinly developed net of social insurance programs, relatively weak protective labor laws, low union density, and decentralized collective bargaining. As indicated previously, the archetype of a LME employment system is the USA - with recognition that within the USA is a considerable degree of diversity in EIR systems that gets glossed over at this high level of abstraction.

The features of the EIR system in a CME are much the opposite. Union density is relatively high, collective bargaining is centralized and plays a large role in wage determination, the state actively consults and coordinates with employers associations and union federations, both labor markets and firms feature a substantial degree of stability and standardization in wages and other economic terms of employment, ILMs are well developed and widespread and employers spend considerable resources on skill development and training, state- and unionmandated employment protection is high, managements have much less flexibility in hiring, pay and termination practices, workers enjoy a wide and generous social safety net of social insurance programs, and workers are given voice through a variety of institutional channels besides unions (e.g., works councils). Germany is the archetypical example of a CME.

VoC thus generates a fairly detailed set of hypotheses for CER analysis - at least for the advanced industrial capitalist countries it largely applies to. It goes further, however, and also 
generates predictions about which type of economy and EIR system yield higher performance (Hall and Soskice, 2001; Streeck and Thelen, 2005). LMEs and CMEs both have performance advantages and disadvantages. The LME, for example, tends to favor radical innovation, gives firms greater flexibility and lower cost, requires lower tax rates and less government bureaucracy and regulation, and benefits from the spur of "do or die" competition. These factors promote economic performance. Working against performance, however, are a mediocre educated and trained workforce, an employee relations climate characterized by more adversarialism, distrust, and free-riding, a short-term "stock market” approach to workforce investment and management, socially corrosive levels of inequality and insecurity, and more boom and bust.

The CME also has performance advantages and disadvantages. On the plus side, for example, are hypothesized factors such as a higher educated and skilled workforce, an employment relationship with greater trust, cooperation and commitment, more stable and noninflationary wage settlements, continuous if incremental innovation and quality improvement, and greater equality and social solidarity. On the downside, the EIR system in a CME is relatively rigid and inflexible, entails higher costs on firms, can make it difficult to terminate employees for poor performance or in economic downturns, and can discourage new business formation and in-country capital investment.

Is there a clear prediction about which variety of capitalism is preferable? Most VoC writers tend to favor the CME model (Streeck , 1998; Hall and Soskice, 2001). On economic grounds, they believe in the long-run a CME outperforms a LME because the former emphasizes a "high road" strategy of growth and development based on skills, cooperation and trust while the LME emphasizes a "low road" strategy of cost cutting, Taylorist work practices (deskilling, narrow training), and an adversarial/low trust climate. In effect, $\mathrm{VoC}$ theorists look at the 
employment relationship as a form of Prisoner's Dilemma game and predict that LME's gravitate toward the low performance “lose-lose” option while CME's are able to move to the high performance "win-win outcome because their EIR systems generate better communication, trust and cooperation among the social partners. Further, they argue that different national business systems develop an institutional comparative advantage and path dependent trajectory and moving from one system to another (e.g., from a CME to LME) can therefore lead to very suboptimal performance (Deeg and Jackson, 2007).

Since this chapter is focused on theory I will not review the extensive empirical literature and accompanying debates on these issues. Suffice it to say, however, the evidence is quite mixed. If attention is focused only on rates of GDP and employment growth, the LMEs appear to win. If a broader set of objectives are considered, including social outcomes such as employment security and income equality, then performance shifts toward CMEs. What this perhaps indicates is again the importance of institutions. Certain countries, such as in the Anglo-American sphere, for historical and cultural reasons favor a more market oriented and individualized EIR system and use political institutions to create rules of the game that favor this type of system and the high GDP growth/high inequality outcomes it produces; other countries, such as in continental Europe, favor a more regulated and collective form of capitalism and use political institutions that set rules of the game that trade-off lower DGP growth for greater security for workers and equality for all parts of society.

\section{Conclusion}

Comparative employment relations has been an active area of research for more than a half century. Whether nations are converging to a common EIR system remains a hotly debated 
question. What can safely be said, however, is that some convergence has taken place in theorizing about the origins of cross-national differences in EIR systems. Nearly all participants agree that an explanation of cross-national variation in EIR institutional architectures is crucial to a viable CER theory. There is also a wide degree of consensus on the types of variables that are important to explaining this diversity in EIR institutions. Following Marxist models, attention must be focused on the nature of national production systems; following neoclassical models attention must also be focused on characteristics of national market systems and the stage of economic development; following human resource management attention must also be given to national differences in EIR strategies among the actors; and following sociology and anthropology attention must be given to cross-national cultural/social traditions and values. EIR also brings its own unique perspective and contribution to CER theorizing, however. It does so partly by melding and synthesizing these other perspectives into an integrated model; it also does so through its own unique concepts and ideas. Central to CER, for example, is the concept of an employment relations system, different models and typologies of ERSs, identification of key variables and constraints that form ERSs, and the role of institutional complementarities. All of this represents a promising beginning; much more, however, awaits to be done -- particularly with respect to greater analytical development. 


\section{References}

Acemoglu, D. (2009), Introduction to Modern Economic Growth, Princeton: Princeton University Press.

Adams, R. (1995), Industrial Relations Under Liberal Democracy, Columbia, SC: University of South Carolina Press. , and N. Meltz. (1993), Industrial Relations Theory: Its Nature and Pedagogy, Metuchen, NJ: Scarecrow Press.

Albert, M. (1993), Capitalism vs. Capitalism, New York: Four Wall Eight Windows.

Amable, B. (2003), The Diversity of Modern Capitalism, Oxford: Oxford University Press.

Aoki, M. (2000), Information, Corporate Governance, and Institutional Diversity, Oxford: Oxford University Press.

Appelbaum, E., Bailey, T., Berg, P., and A. Kalleberg (2000), Manufacturing Advantage: Why High-Performance Work Systems Pay Off, Ithaca, NY: Cornell University Press.

Arthur, J. (1992), “The Link Between Business Strategy and Industrial Relations Systems in American Steel Minimills,” Industrial and Labor Relations Review, 45, 488-506.

Bamber, G., Lansbury, R., and N. Wailes. (2004), International and Comparative Employment Relations, $4^{\text {th }}$ ed, New York: Sage.

Barbash, J. (1984), The Elements of Industrial Relations, Madison, WI: University of Wisconsin Press.

Barbash, J., and K. Barbash. (1989), Theories and Concepts in Comparative Industrial Relations, Columbia, SC: University of South Carolina Press.

Bean, R. (1994), Comparative Industrial Relations, $2^{\text {nd }}$ ed, New York: Routledge.

Begin, J. (1991), Strategic Employment Policy: An Organizational Systems Perspective, Englewood Cliffs, NJ: Prentice-Hall.

Begin, J. (1997), Dynamic Human Resource Systems: Cross-National Comparisons, New York: De Gruyter.

Blum, A. (1981), International Handbook of Industrial Relations, Westport, CT: Greenwood Press.

Blyton, P., and P. Turnbull. (2004), The Dynamics of Employee Relations, $3^{\text {rd }}$ ed, London: Palgrave Macmillan. 
Boxall, P., and J. Purcell. (2008), Strategy and Human Resource Management, $2^{\text {nd }}$ ed, New York: Palgrave Macmillan.

Brewster, C., G. Wood, and M. Brookes. (2006), "Varieties of Capitalism and Varieties of Firms,” in G. Wood and P. James (eds), Institutions, Production, and Working Life, Oxford: Oxford University Press, pp. 217-34.

Briscoe, D., Schuler, R., and L. Claus. (2009), International Human Resource Management: Policies and Practices for Multinational Corporations, $3^{\text {rd }}$ ed, New York: Routledge.

Budd, J. 2004. Employment With a Human Face: Balancing Efficiency, Equity, and Voice, Ithaca: Cornell University Press.

Coase, R. (1937), “The Nature of the Firm,” Economica 4 (November), 386-405.

. (1992), “The Institutional Structure of Production,” American Economic Review, 82,

713-19.

Cochrane, J. (1979), Industrialism and Industrial Man in Retrospect, Ann Arbor, MI: University of Michigan Press.

Commons, J. (1919), Industrial Goodwill, New York: McGraw Hill. . (1934), Institutional Economics: Its Place in Political Economy, New York: Macmillan.

Crouch, C. (1993), Industrial Relations and European State Traditions, Oxford: Clarendon Press.

Crouch, C. (2005), Capitalist Diversity and Change, Oxford: Oxford University Press.

Deeg, R., and G. Jackson. (2007), “Toward a More Dynamic theory of Capitalist Development,” Socio-Economic Review, 5, 149-79.

Doeringer, P. 1981. Industrial Relations in International Perspective, New York: Holmes \& Meier. , and M. Piore. 1971. Internal Labor Markets and Manpower Analysis, Lexington: Lexington Books.

Dore, R. (1973). British Factory, Japanese factory: The Origins of National Diversity in Industrial Relations, Berkeley, CA: University of California Press. 
Dore, R. (2000), Stock Market Capitalism: Welfare Capitalism, Oxford: Oxford University Press.

Dunlop, J. (1958), Industrial Relations Systems. New York: Holt.

Durkheim, E. (1895/1938), Rules of the Sociological Method, $8^{\text {th }}$ ed. Glencoe, ILL: Free Press.

Edwards, P. (2003), “The Employment Relationship and the Field of Industrial Relations,” in P. Edwards (ed), Industrial Relations: Theory and Practice, $2^{\text {nd }}$ ed., London: Blackwell, pp. $1-36$.

Edwards, R. (1979), Contested Terrain: The Transformation of the Workplace in the Twentieth Century, New York: Basic Books.

Ferner, A., and R. Hyman. (1992),. Industrial Relations in the New Europe, London: Blackwell.

Flanders, A. (1965), Industrial Relations: What's Wrong With the System? An Essay on its Theory and Future, London: Faber and Faber.

Godard, J. (2004), “The New Institutionalism, Capitalist Diversity, and Industrial Relations,” in B. Kaufman (ed), Theoretical Perspectives on Work and the Employment Relationship, Champagne, IL: Industrial Relations Research Association, pp. 229-64.

Goldthorpe, J. (1984), Order and Conflict in Contemporary Capitalism, Oxford: Oxford University Press.

Gospel, H., and A. Pendleton. (2005), Corporate Governance and Labour Management, Oxford: Oxford University Press.

Hall, P., and D. Soskice. (2001), Varieties of Capitalism: The Institutional Foundations of Comparative Advantage, Oxford: Oxford University Press.

Hall, R., and N. Wailes. (2010), "International and Comparative Human Resource Management," in A. Wilkinson, N. Bacon, T. Redman, and S. Snell (eds), The Sage Handbook of Human Resource Management, New York: Sage, pp. 115-32.

Hamann, K., and J. Kelly. (2008), "Varieties of Capitalism and Industrial Relations," in P. Blyton, N. Bacon, J. Fiorito, and E. Heery (eds), The Sage Handbook of Industrial Relations, New York: Sage, pp. 129-48.

Hancké, B., Rhodes, M., and M. Thatcher. (2007), "Introduction: Beyond Varieties of Capitalism," in B. Hancke, M. Rhodes, and M. Thatcher (eds), Beyond Varieties of Capitalism, Oxford University Press, pp. 3-38. 
Harbison, F., and I. Ibrahim. (1958), Human Resources in Egyptian Enterprises, New York: McGraw-Hill.

Hills, S. (1995), Employment Relations and the Social Sciences, Columbia, SC: University of South Carolina Press.

Hodgson, G. (1998), Foundations of Evolutionary Economics, 1890-1973, Northampton, MA: Edward Elgar.

Hodgson, G. (2002), “Institutional Blindness in Modern Economics,” in J. Hollingsworth, K. Müller, and E Hollingsworth (eds), Advancing Socio-Economics: An Institutionalist Perspective, Boston: Rowman \& Littefield, pp. 147-70.

Hollingsworth, J. (2002), “On Institutions,” in J. Hollingsworth, Karl Müller, and E. Hollingsworth (eds), Advancing Socio-Economics, London: Rowman and Littlefield, pp. 83-87.

Hollingsworth, J. and R. Boyer. (1998), Contemporary Capitalism: The Embeddedness of Institutions, Cambridge: Cambridge University Press.

Hyman, R. (1975), Industrial Relations: A Marxist Introduction, London: Macmillan.

Hyman R. (2001), European Trade Unionism: Between Market, Class and Society, London: Sage.

Hyman, R. (2004), “Is Industrial Relations Theory Always Ethnocentric?” in B. Kaufman (ed), Theoretical Perspectives on Work and the Employment Relationship, Champagne, IL: Industrial Relations Research Association, pp. 265-92.

Jessop, B. (2002). "The Social Embeddedness of the Economy and Its Implications for Economic Governance," in F. Adaman and P. Devine (eds), Economy and Society: Money, Capitalism and Transition, New York: Black Rose Books, pp. 192-224.

Katz, H., and O. Darbishire. (2000), Converging Divergences: Worldwide Changes in Employment Systems, Ithaca: Cornell University Press.

Kaufman, B. (1993), The Origin and Evolution of the Field of Industrial Relations in the United States, Ithaca, NY: ILR Press.

Kaufman, B. ( 2004a), The Global Evolution of Industrial Relations: Events, Ideas, and the IIRA. Geneva: ILO. 
Kaufman, B. (2004b), Theoretical Perspectives on Work and the Employment Relationship, Champagne, IL: Industrial Relations Research Association.

Kaufman, B. (2004c), "Employment Relations and the Employment Relations System: A Guide to Theorizing," in B. Kaufman (ed.), Theoretical Perspectives on Work and the Employment Relationship, Champaign, IL: Industrial Relations Research Association, pp. 41-75.

Kaufman, B. (2008), "Paradigms in Industrial Relations: Original, Modern, and Versions In -between,” British Journal of Industrial Relations, 46 (June), 314-39.

Kaufman, B. (2010), “The Theoretical Foundation of Industrial Relations and Its Implications for Labor Economics and Human Resource Management,” Industrial and Labor Relations Review (forthcoming).

Kerr, C. (1950), Labor Markets: Their Character and Consequences,” American Economic Review, 40, 278-91.

Kerr, C. (1954), “The Balkanization of Labor Markets,” in E. Bakke (ed), Labor mobility and Economic Opportunity, Cambridge: MIT Press, pp. 92-110.

Kerr, C. (1960), Industrialism and Industrial Man, Cambridge: Harvard University Press.

Kesting, S., and K. Nielsen. (2008), "Varieties of Capitalism: Theoretical Critique and Empirical Observation,” in W. Elsner and H. Hanappi (eds), Varieties of Capitalism and New Institutional Deals, Northampton, MA: Edward Elgar, pp. 23-52.

Lepak, D., \& Snell, S. (1999), "The Human Resource Architecture: Toward a Theory of Human Capital Allocation and Development," Academy of Management Review, 24, 31-48.

Levine, S., and H. Kawada. (1980), Human Resources in Japanese Industrial Development, Princeton: Princeton University Press.

Locke, R., Kochan, T., and M. Piore. (1995), Employment Relations in a Changing World Economy, Cambridge: MIT Press.

Marsden, D. (1999), A Theory of Employment Systems: Micro Foundations of Societal Diversity, Oxford: Oxford University Press.

Martin, R., and G. Bamber. (2004), "International Comparative Employment Relations Theory: Developing the Political Economy Perspective,” in B. Kaufman (ed), Theoretical Perspectives on Work and the Employment Relationship, Champagne, IL: Industrial Relations Research Association, pp. 293-321. 
Müller-Jentsch, W. (2004), “Theoretical Approaches to Industrial Relations,” in B. Kaufman (ed), Theoretical Perspectives on Work and the Employment Relationship, Champaign, IL: Industrial Relations Research Association, pp. 1-40.

Myers, C. and S. Kannappan. (1970), Industrial Relations in India, New York: Asia Publishing House.

North, D. (2005), Understanding the Process of Economic Growth, Princeton, NJ: Princeton University Press.

Orlitzky, M, \& S. Frenkel. (2005), “Alternative Pathways to High Performance Workplaces, International Journal of Human Resource Management, 16, 1325-48.

Osterman, P. (1987), “Choice of Employment Systems in Internal Labor Markets,” Industrial Relations, 26, 46-67.

Piore, M. \& C. Sabel. (1984), The Second Industrial Divide: Possibilities for Prosperity. New York: Basic Books.

Polanyi, K. (1944), The Great Transformation, New York: Farrar and Rinehart.

Poole. M. (1986), Industrial Relations: Origins and Patterns of National Diversity, London: Routledge \& Kegan.

Rubery, J., \& D. Grimshaw. (2003), The Organization of Employment: An International Perspective, London: Palgrave Macmillan.

Simon, H. (1951), “A Formal Theory of the Employment Relationship,” Econometrica, 19, 293 $-305$.

Smith, A. (1776/1937), An Inquiry into the Nature and Causes of the Wealth of Nations. New York: Modern Library.

Strauss, G. (1998), “Comparative International Industrial Relations,” in K. Whitfield and G. Strauss (eds), Researching the World of Work, Ithaca, NY: Cornell University Press, pp. 175-92.

Streeck, W. (1998). "Beneficial Constraints: On the Economic Limits of Rational Voluntarism," in J. Hollingsworth and R. Boyer (eds), Contemporary Capitalism: The Embeddedness of Institutions, Cambridge: Cambridge University Press, pp. 197-219.

Streeck, W., and K. Yamamura. (2001), The Origins of Nonliberal Capitalism: Germany and Japan in Comparison, Ithaca, NY: Cornell University Press. 
Streeck, W., and K. Thelen (2005), Beyond Continuity: Institutional Change in Advanced Political Economies, Oxford: Oxford University Press.

Stryker, R. (2002), "The Future of Socio-Economics and of the Society for the Advancement of Socio-Economics," in J. Hollingsworth, K. Müller, and E Hollingsworth (eds), Advancing Socio-Economics: An Institutionalist Perspective, Boston: Rowman \& Littefield, pp. 5158.

Thompson, P., \& B. Hartley. (2007), "HRM and the Worker: Labor Process Perspectives,” in P. Boxall, J. Purcell, and P. Wright (eds), Oxford International Handbook of Human Resource Management, Oxford: Oxford University Press, pp. 147-65.

Toh, S, Morgeson, F, and M. Campion. (2008), "Human Resource Configurations: Investigating Fit with the Organizational Context,” Journal of Applied Psychology, 93, 864-82.

Van Ruysseveldt, J., Huiskamp, R., and J. van Hoof. (1995), Comparative Industrial and Employment Relations, London: Sage.

Wailes, N., Kitay, J., and R. Lansbury. (2008), "Varieties of Capitalism, Corporate Governance and Employment Relations Under Globalization,” in S. Marshall, R. Mitchell, and I. Ramsay (eds), Varieties of Capitalism, Corporate Governance and Employees, Melbourne, AU: Melbourne University Press, pp. 19-38.

Whitley, R. (1999), Divergent Capitalisms, Oxford: Oxford University Press.

Whitley, R. (2005), "How National are Business Systems? The Role of States and Complementary Institutions in Standardizing Systems of Economic Coordination and Control at the National Level,” in G. Morgan, R. Whitley, and E Moen (eds), Changing Capitalisms? Internationalization, Institutional Change, and Systems of Economic Organization, Oxford: Oxford University Press, pp. 190-231.

Williamson, O. (1975). Markets and Hierarchies, New York, Free Press.

Yeung, H. (2000), "The Dynamics of Asian Business Systems in a Globalizing Era," Review of International Political Economy, 7, 399-433. 